\title{
The ghost of national final exams that (still) haunts the Indonesian school libraries' information literacy activities and students' reading interests: a preliminary study
}

\author{
L. Sulistyo-Basuki \\ Library and Information Science Program \\ School of Graduate Studies Universitas Indonesia \\ Kampus UI Depok, Depok 16424,Indonesia \\ Email: sbasuki@indosat.net.id
}

\begin{abstract}
s
The Indonesian government introduced the compulsory-nation-wide National Exam (called Ujian Nasional in Bahasa Indonesia shortened to UN) since 2005. The systems required the students of class 6,9 and 12 to pass the National Exam in certain courses. This paper limits to class 12 as they will enroll to higher education. For class 12 there are threee compulsory courses, that are Indonesian Language, English and mathematics. As class 12 was divided into three departments (i.e. natural sciences, social sciences and language), each students must participate in the related-courseexams such those who choose natural sciences must take Physics, Chemistry, Biology; for social sciences the students must take Economics, Geography, Sociology while those from language department must take Indonesian literature, Anthropology and selected foreign languages (Chinese n, Japanese, German, Arab language) respectively. As the National Exam are compulsory, then the schools teach the students mostly in those subjects, sometime sacrificing other courses, the students are crammed only the required courses. Indirectly the students supported by the teachers are involved in information literacy activities albeit limited to certain subjects and usually using widely internet and google (a disadvantage for students with limited technological infrastructure and not 24 hours-electricity facilitiy). As being drilled into National Exam required courses, then the students are not really complete information literate person, they just partly information literate. Sacrificing other subjects, the students do not read literary books, they just read the novel excerps(!) This findings supported the acclaimed Indonesian poet Taufik Ismail who denoted that the Indonesian high school students since 1970s do not literary works at all. Apart from the (controversial) National Exam systems, from library point-of-view it is suggested that the school libraries actively took part in the information literacy holistically not partially in order to support the life long learning through information literacy program
\end{abstract}

Key words: Indonesia, school libraries, reading interest, Information literacy, National exam 


\section{Introduction}

Indonesia is an archipelago nations, consists of 17,508 islands (Indonesia,2010), if superimposed on Europe it spread from London in the west to Black Sea in the east or for USA, from Los Angeles in the West to mid-distance somewhere between New York and Bermuda islands. Although it is a wide are, the economic and educational conditions is not the same, with the better ones is considered available in the island of Java Indonesia's population is about 240 million, making her the fourth most population nation in the world, after China, India, and United States.

\section{Educational System}

Based on Act of National Education System, 2003 (Undang-Undang 2003), article 17) the educational systems consists of (1)Primary school and (2) High schools. Primary school is school from class 1 to 9 while high school class 10 to 12. This new system is slightly different from its earlier acts which divided into primary school (class 1 to 6 ), junior high school (class 7 to 9 ) and senior high school (class 10 to 12).

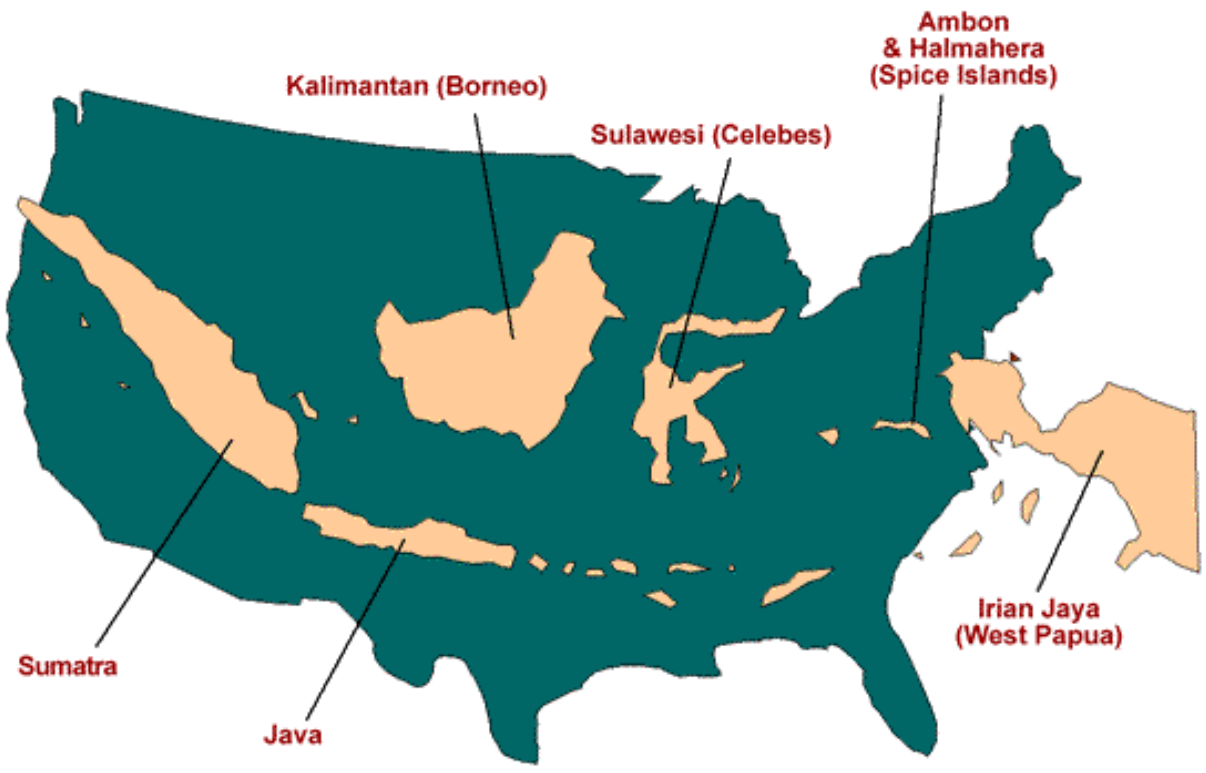

Fig 1 Indonesia superimposed into USA

The size of Indonesia compared to the U.S.

Indonesian land mass superimposed over a map of the United States 


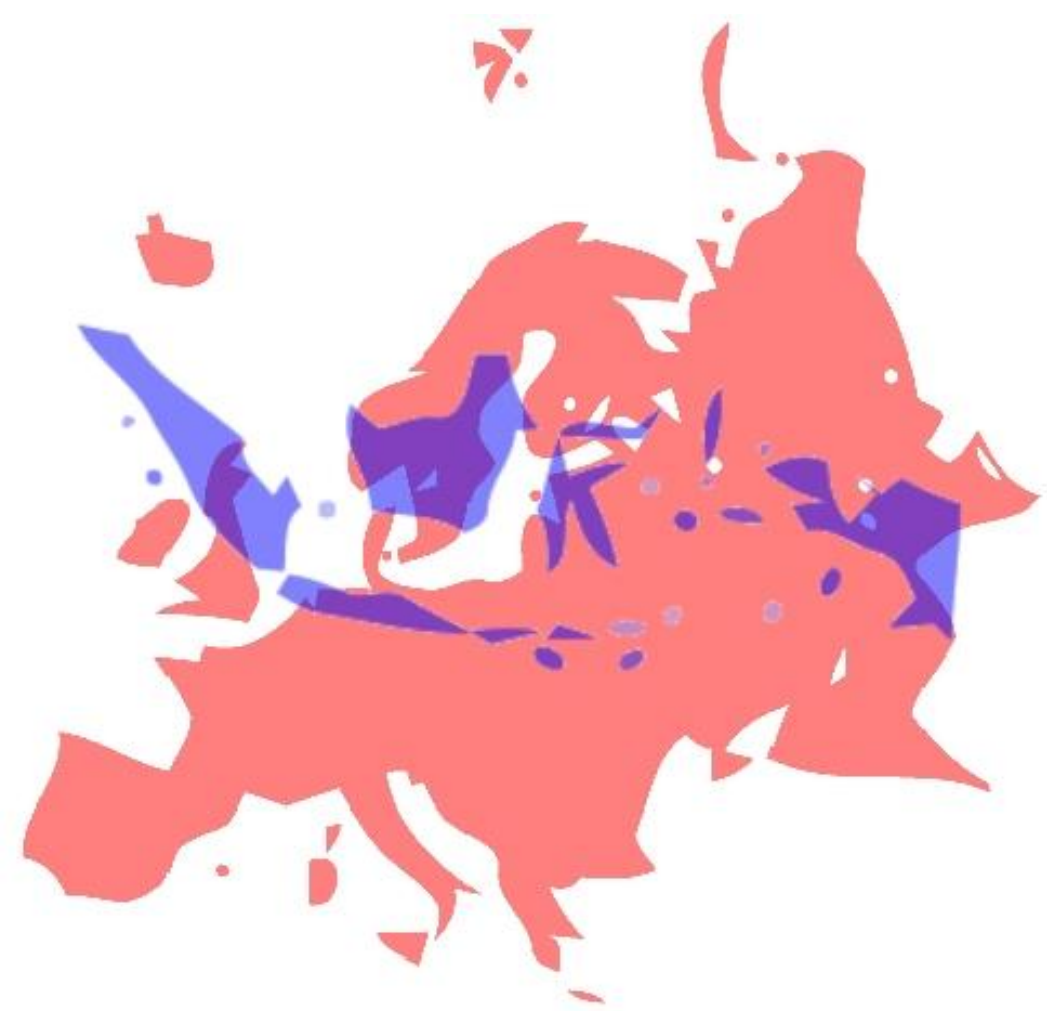

Fig 2 Indonesia superimposed to Europe http://pomenvadrouille.files.wordpress.com/2012/05/indonesiavseurope.jpeg 256-2013

'Based on 2003 National Education Act, there are three high school types, that are (public) high school, Islamic based high school under the supervision of the Ministry of Religious Affairs (called Madrasah Aliyah) and vocational school. This paper limits the discussion to (public) high school, hereafter called high school. In high school there three specialization i.e. Natural Science (IImu Pengetahuan Alam in Bahasa Indonesia), Social Sciences (IImu Pengetahuan Sosial) and Language (Bahasa). . The specialization begin at class 11 after the student be promoted from class 10 to class 11 . The specialization decides what schools he or she choose after finishing his or her high school education. For example those who choose Social science or Language are not allowed to enroll at the school of medicine or engineering as their courses in high schools is considered not good enough to attend mathematical or engineering-related courses at the university level. Meanwhile those students whose specializations are social science or cultural studies could enroll at another schools such as school of law, economic, language etc. On the other hand, those high school students whose specialization in natural science could enroll at school of law, economic, language etc. It is a discrimination going back to educational systems introduced by the government of Netherlands East Indies and still inherited until present times. 


\section{Research Methods}

For writing this paper, the research methods used consists of using the available documents, either open or grey literature, interviews with selected headmasters and teachers, followed by a questionnaire for the freshly enrolled students who enrolled at the Department of Library and Information Science University of Indonesia for school year 2010 and 2011.

Owing to the sensitivity of the items (National Exam) as well the questions related, all correspondents answered on condition that their names are remained to be anonymous, The survey is limited to students from high schools, either public or private, but excluding the religion and vocational high schools and limited to the current National Exam only. Also it is not included the final exams for class 6 and 9 respectively.

\section{The National Exam}

National Exam (in Bahasa Indonesia called Ujian Nasional) is a standard evaluation system of primary and secondary education in Indonesia and the equation of quality of education levels among the areas that conducted by the Center for Educational Assessment, Ministry of National Education. It based on Act of National Education Systems , act no 12 the year 2012 that states that in order to control the quality of education nationwide to be evaluated as a form of accountability of education providers to the parties concerned The National Exam in compulsory for class 6 (covering Bahasa Indonesia(Indonesian language), Mathematics and Science), Class 9 (Bahasa Indonesia, Mathematics, Science and English language) while for High School (class 12) is different according the specialization chosen by each students.

The present National Exam are a continuation of the previous nationwide exams although with different names (Table 1)

\section{TABLE 1 VARIOUS NAMES OF STATE FINAL EXAMS}

\section{Type of exams}

State examination (Ujian Negara)

School examination (Ujian Sekolah)

Final phase learning evaluation

(Evaluasi Belajar Tahap Nasional)

National Final Exams (Ujian Akhir

Nasional)

National Exam (Ujian Nasional)

\section{Period}

1965-1971

1972-1979

$1980-2000$

$2001-2004$

2005-

present

Source: Sulistyo (2013) compiled from various sources

For high school, the National Exam consists of common subjects and special one (Table 2) 


\section{Table 2 Subjects for National Exam}

\begin{tabular}{ll} 
Specialization & \multicolumn{1}{c}{$\begin{array}{c}\text { Common } \\
\text { course }\end{array}$} \\
Natural \\
science
\end{tabular}

Religion

Kejuruan

\section{Specialization courses}

Physics, Chemistry, Biology

Economics, Geography, Sociology

Indonesian Literature

Anthropology

Choice of one foreign language (Chinese, Japanese, German, French, Arabic language)

Exegesis, Hadith, Fiqih (Islamic Law)

Vocational theories

The common courses that must be taken by every class 12 students regardless his or her specialization are Indonesian language, English and Mathematics. Then every students must take the other compulsory exams materials according to their specialization.(Table 2)..

Since the national exam is compulsory for the class 12 students, since class 11 the students are drilled and geared toward national exam. In many schools, the school conducted extra learning for the class 12 students even some of them attended extra courses provided by private institutions or by the teacher after the school time. With the passing-the-national-exams-oriented programs, then the school deleted or minimize other courses not related to national exam courses so that the students could concentrate for the national exams. Questions posed to school librarians on the relation of national exam with school library were met with just shrug and this answer is common among the respondents. The students rarely used the library for various reasons (such as the library opening hour is limited, the books are out of date, library building located on the far side of the schools etc), on the other hand the school library just provide the textbooks as most of the books are kept in the library and no information literacy activities were involved. The national exam was conducted on April and its result was announced in the month of June every year.Although conducted nationwide, the exams are in the form of multiple choice, so it is easier to process.

\section{The Impact Toward School Librarianship}

The National Exam has various impacts toward school librarianship . First, the students are not involved in various phase of information literacy If we talk about the information literacy (IL), the preparation is not suited to the concept of information literacy of various models for K-12 (for example Information Literacy Standards, 2007; UNESCO Information, 2007) The students are drilled for the national exam. What the teacher did is supplying the previous year exams material, concentrated on the exam courses only and more often the class 12 students looking for information in Internet. Preparing the National Exam, the students use a part of literacy information activities, more on searching, locating the sources; it can be said that it is a partial approach not the holistic approach . Many school librarian are baffled with concept of information literacy, hence they don't know whether $f$ the students covered information literacy activities 
such identify, explore, select, organize, create, present, assess, apply (Wijetunga and Alhakoon, 2005) or other various models such as The Big6 ${ }^{\mathrm{TM}}$, Plus Model etc. . School librarians are not involved with the preparation of National Exam as the headmaster, teachers and students considered they can find the information in the Internet. However, this is also can be accredited to the not always good school libraries.

Second The National Exam has not good impact toward reading interests. For eight consecutive years the worst result in Nationbal Exam is always on Bahasa Indonesia or Indonesian language test. . The bad results in Bahasa Indonesia exam can be explained as follows. First, the students think that being speaking Bahasa Indonesia in daily life, then it is not necessary to learn further the language. They think $t$ that their spoken ability is a guarantee to pass the exam. Second, the teaching of Bahasa Indonesia is limited, no more than 4 hours a week which should cover grammatical aspects as well as Indonesian literature. With such limited time, the teacher has not enough time to introduce works of Indonesian authors, Third, the student very rare got reading course on Indonesian literary works, so when students encountered in national exam a reading material then instructed to answer the questions, they could not it done properly because of lack of reading experience...The students are more concentrated on the subject and considered reading the classic literature is waste of time. For Indonesian language National Exam,, hardly any question s regarding national literary books, let alone world literary one. The exam consist of reading a text of no more than 200 words, then students answered the question by selecting the choices.

Taufik Ismail (a noted Indonesian poet) together with literature journal Horizon conducted research on reading of literature works in 13 countries.(Table 3)

Table 3 Required literary books for high school

\begin{tabular}{|c|l|l|l|c|}
\hline No & School location & $\begin{array}{l}\text { Required } \\
\text { books }\end{array}$ & $\begin{array}{l}\text { High school or } \\
\text { town name }\end{array}$ & Period \\
\hline 1 & Southern Thailand & 5 titles & Narathiwat & $1986-1991$ \\
\hline 2 & Malaysia & 6 titles & Kuala Kangsar & $1976-1980$ \\
\hline 3 & Singapore & 6 titles & Stamford College & $1982-1983$ \\
\hline 4 & Brunei Darussalam & 7 titles & $\begin{array}{l}\text { Sekolah Menengah } \\
\text { Melayu I }\end{array}$ & $1966-1969$ \\
\hline 5 & Soviet Union & 12 titles & Uva & 1980 s \\
\hline 6 & Canada & 13 titles & Canterbury & $1992-1994$ \\
\hline 7 & Japan & 15 titles & Urawa & $1969-1972$ \\
\hline 8 & $\begin{array}{l}\text { Swiss (International } \\
\text { High School) }\end{array}$ & 15 titles & Geneva & $1991-1994$ \\
\hline 9 & West germany & 22 titles & Wanne-Eickel & $1966-1975$ \\
\hline 10 & France & 30 titles & Pontoise & $1967-1970$ \\
\hline 11 & Netherlands & 30 titles & Middleburg & $1970-1973$ \\
\hline 12 & United States & 32 titles & Forest Hills & $1987-1989$ \\
\hline 13 & $\begin{array}{l}\text { Netherlands East } \\
\text { Indies* }\end{array}$ & 25 titles & $\begin{array}{l}\text { Algemeen } \\
\text { Middlebare School } \\
\text { A, Yogyakarta** }\end{array}$ & $1939-1942$ \\
\hline 14 & Netherlands East & 15 titles & Malang & $1929-1932$ \\
\hline
\end{tabular}




\begin{tabular}{|l|l|l|l|c|}
\hline No & School location & $\begin{array}{l}\text { Required } \\
\text { books }\end{array}$ & $\begin{array}{l}\text { High school or } \\
\text { town name }\end{array}$ & Period \\
\hline & Indies & & & \\
\hline 15 & Indonesia & 0 titles & Anywhere & $1943-2005$ \\
\hline
\end{tabular}

Source: Taufik Ismail (2005)

Note: * the name of Indonesia during Netherlands administration, prior to 1942

** Senior High School, A denoting the Language specialization while B for natural science.

The findings is related with the National Exam results in which the worst grade is for Bahasa Indonesia for all students. In Indonesia there is no compulsory reading for literature works, so since 1970s the high school students didn't read literary works at all. This is a deterioration, as the during the Netherlands East Indies government which administered Indonesia until 1942, each high school students read at least 25 literature works. The poet Taufik Ismail noted that from 1970s onward, Indonesia only producing Zero Book Generation (generasi nol buku) as the high school students in their three year studies never read any book at all (except t textbooks)!

The author of this paper also conducted questionnaire for the fresh students who enrolled at the department of library and information science at University of Indonesia for academic year 2010 and 2011. The question is:

What you read the last three months, excluding textbooks?

Who is writing Perburuan (The fugitive)

What literary books you read for the last three months?

Mention the book you prefer most.

For the first question, about $40 \%$ read books, mostly on religious one. On the second question, not all answered correctly (the answer is the late Pramoedya Ananta Toer (1925-2006). For the third question, only ten out of 100 students who read Indonesian literary books while the others just read the excerpt(!) and some even added that its is useless to read Indonesian literary books as it is not posed at the National Exam. For the third question, the answers varies. However, some of them read Book Laskar Pelangi( Rainbow warriors, Rainbow heroes) by Andrea Hirata The novel written in a period of six months, was based on his childhood experiences in Belitung; he later described it as "an irony about lack of access to education for children in one of the world's wealthiest islands." (Jakarta Post, 2010) The novel went on to sell five million copies, with pirated edition selling 15 million more (Riady, 2010) The novel went on to sell five million copies, with pirated editions selling 15 million more. By 2012 the English translation of his work Laskar Pelangi had been picked up by Farrar, Strauss and Giroud (FRG), Penguin Books and Random House for sale in twenty countries. In an informal discussion with freshman of 2010 dan 2011 class; it was obvious that more than $50 \%$ of students watched the Laskar Pelangie movie. Regarding the fourth question i.e. do they read Indonesian literary books, the students answered that they read only the excerpts not the books itself! They said its is easier than reading the original books, the excerpts are available from various sources and no questions asked on the National Exams. . On further question regarding poetry, less than the one hand fingers who liked poetry. The majority freshmen knew one or two poems by Chairil Anwar (1922-1949), especially Kerawang Bekasi and Aku (I) albeit his poems 
have been translated into English ,Russian, German andArabic). This preliminary survey showed that National Exam doesn't encourage students to read literary works.

Third, the uncertain role of school libraries in the wake of National Exam. As the National Exam being a part of National Educational Systems, it will continue further, then the process is the same; the students are preparing for National Exam, no need to read literary books as it is not covered by the exams and the process of zero-book generation will continue It is not surprising that the litany of suffering of school libraries still continues (Sulistyo, 2007). The uncertainties also can be attributed to changing policy on school librarians and the not-yet-fully-application of national standard. The current rules (Kementerian Pendidikan, 2008) stated that the former headmaster who is no longer functions as headmaster can occupy the job as the head of school libraries after conducting certain training; however, it is only 60 hours meeting! (Dr Zulfikar Zen, interview by author, Jakarta, Indonesia, July 9, 2013). Librarians consider it as not fair as the students study from two to four years and supervised by a-sixtyhour-training officials(read headmaster) and contrary to the Act no 43 of 2007 on Libraries (Undang-Undang Perpustakaan, 2007; Respatiningsih, 2012) which stated the library must be manned trained librarian.

Perpustakaan Nasional or National Library (2007)noted that there are 8,238 high schools with 5,598 librarians but doesn't mentioned the trained librarians while Dwiyogo (2011) noted that in 2005, there 7,989 high school, with 5,716 high school libraries staffed by 5,247 person, but with only 220 trained librarians. Trained librarians are not always a bachelor or diploma three degree holders, they can be librarian whose trainings are provided by the National Library of Indonesia and the training duration is 3 months training or less.

Based on the findings, the ghost of National Exam still haunt the information literacy program with partially but not holistic approach., while the Indonesian language exam does not encourage students to read literary works which in turn produces a zero book generation. Meanwhile the role of schools librarians in relation to National Exam is not obvious, partly to the school libraries condition itself (lack of good books, opening hours, manpower problems ) but partly also to the headmaster, teachers and studenbts'attitute toward school libraries.

\section{Conclusion and suggestion.}

Apart from the controversies regarding National Exam (Abbas, 2013;Murzaki, 2013), National Exam does not encourage information literacy holistic approach, as the class 12 students are preparing only for the exams, they don't necessarily using the information literacy models, more on cognitive skills but less on affective skills, reading and culture literacy. Also it doesn't emphasize reading literary works as the question on Bahasa Indonesia national exam does not stress on Indonesian literature. The impact is the class 12 students don't read literary books which the Indonesian poet Taufik Ismail called them as the nobook generation or the generation that never read any books! (Ismail, 2005, Taufik , 2005, 2013)

It is suggested that there are improvements for school libraries, including the budget (the school library standard stated that the minimum budget is $5 \%$ of the school budget; (Perpustakaan Nasional, 2009), library policy, manpower and 
its activities should relate to National Exam as well as other information-related works

\section{References}

Abbas, Hafid. 'Quo Vadis” Ujian Nasional (Quo Vadis National Exam). http://acdpindonesia.files.wordpress.com/2013/04/kompas-p6-1.jpg Download on August 5, 2013.

Dwiyogo, Wasis. (2012). Sumber daya manusia perpustakaan sekolah (School libraries human resources). Unpublished paper for Training Courses for School Librarians, Bandung, October 15.

Indonesia.(2010). $9^{\text {th }}$ ed. London:Lonely Planet

Information Literacy Standards K-12:a continuum of library, research andtechnology skills. (2007). Marin CXountry,California: Marina CXountty ETF Information Literacy Skills.

Ismail, Taufik. (2005). Tragedi nol buku, tragedy kita bersama.(Zero book tragedy is our tragedy). Paper for Indonesian Library Association Meeting, Pekanbaru, Riau, 2005

Jakarta Post, 1 September 2008. "Hirata happy with Laskar Pelangi." Jakarta Post, January 13, 2012. www.webcitation.org/64eySgjd3. download 12th August, 2012

Muzaki, Ferril Irham. DoesNational Exam (UN) really an examination?http://imo2.thejakartapost.com/2013/04/02does-national... Download on August 11,2013.

Perpustakaan Nasional. (2007) Literasi informasi (information literacy): pengantar untuk perpustakaan sekolah. Jakarta:2007. (Information literacy: an introduction for school libraries)

Perpustakaan Nasional.(2009)Perpustakaan sekolah SNI 739:2009 (Standard on school libraries)

Riady,Stephanie (2010.)"Exporting Indonesia's Written Word." Jakarta Globe January 28, 2012. www.webcitation.org/6512Xcv03. Download August 12, 2013

Respatingsih, B. Endang Sudarti. (2012). Kegelisahan Pustakwan Sekolah Menyikapi Permendiknas nomor 25 tahun 2008." (School librarians'uneasiness on 2008 Ministry of National Education iedict on school librarian) (http://buletinpustaka.blogspot.com/2012/07/kegelisahanpustakawan-s... Download 29 July 2012.

Sulistyo-Basuki-Basuki. (2005). The litany of suffering is still heard but not louder: a case study on clinical supervision to school libraries in Indonesia's four provinces. IASL Conference 
Taufik Ismail:Bangsa Indonesia Generasi Nol

Buku. www.melayuonline.com.Download $1^{\text {st }}$ August 2013. (Taufik ismail: Indonesian People Zero Book generation)

Wijetunga, P and Alahakoon,U. (2005). Empowering 8: the Information Literacy Model Developed in Sri Lanka to Underpin Changes of Educational Paradigms of Sri Lanka. Journal of Librarianship \& Information Management,1(1),31-40. http://www.cmb,ac.lk/academic/ download 1 August 2013

Undang-Undang nomor 20 tahun 2003 tentang Sistem Pendidikan Nasional. (2003)

(Act no 20, 2003 on National Educational System)

Undang-Undang nomor 43 tahun 2007 tentang Perpustakaan (2007). (Act no 43, 2007) on library.

UNESCO Information for All Programme. (2007) Understanding Information Literacy: A Primer. Paris:UNESCO

\section{Biography}

Sulistyo-Basuki got his Sardjana (1963) and Sarjana degrees (1974) from University of Indonesia, Master of Science in Library Science and Master of Arts from Case Western Reserve University in Cleveland, Ohio, USA on 1980) and Doctor of Philosophy also from Case Western Reserve University with dissertation "A citation analysis of Agricultural and <edical journals published in Less Developed Countries, with Special reference to the Regions of Africa SubSahara, Latin America and Southeast Asia". Has been working in various libraries (1962-1977), consultant for school library projects (late 1990s and early 2003s) and lecturing from 1977 to 2006 . Retired as professor in 2006, but extended until present times. Published books and articles (more than 800 articles), the recent one is Daftar Tajuk Subjek dalam Bahasa Indonesia (2013) (Subject Headings in Indonesian Language) specially designed for school and public libraries. 